\title{
URBAN OR MORAL DECAY?: THE CASE OF TWENTIETH CENTURY DETROIT
}

\author{
Carolyn FAHEY \\ Planning, Housing and Sustainability, City of Boulder, 1739 Broadway, Boulder, Colorado, USA \\ E-mail: carfahey@gmail.com
}

Received 13 June 2016; accepted 13 February 2017

\begin{abstract}
This paper provides an alternative narrative of Detroit from one of economic struggle and racial division. It instead discusses other forces at play, focusing on questionable moral standing and its relationship to built form, specifically the city. The paper explores whether a compelling claim on building's moral use can be established, and in doing so seeks to establish a causal link between moral relationship and the built environment. Moral relationship is established through three main avenues. The first is a brief discussion of Detroit's history, particularly its history from WWII onward, in order to establish the complex moral context into which this argument is situated. The second avenue provides a concise summary of Stanley Cavell's moral framework and discusses the conundrum of having moral obligation in the absence of moral relationship. The final avenue is a look to the famous Renaissance Center as emblematic of the moral relationship at play. The resulting form of analysis relies on the premises that buildings can embody the knowledge and agreement required for (moral) relationship, and that buildings are artifacts of moral relationship. The paper concludes that buildings are therefore morally appraisable, which is to say they can be appraised for their moral appropriateness.
\end{abstract}

Keywords: urban planning, architecture, ethics, Detroit, housing, economics, justice, morality, philosophy, Cavell.

The dying was a slow process, but in the midst of urban decay fresh life sprouts, like seeds from garbage on a compost heap. The new vision that made the new life possible gave a positive value to all the negations and defeats that the tried peoples had experienced.

- Lewis Mumford, The City in History ${ }^{1}$

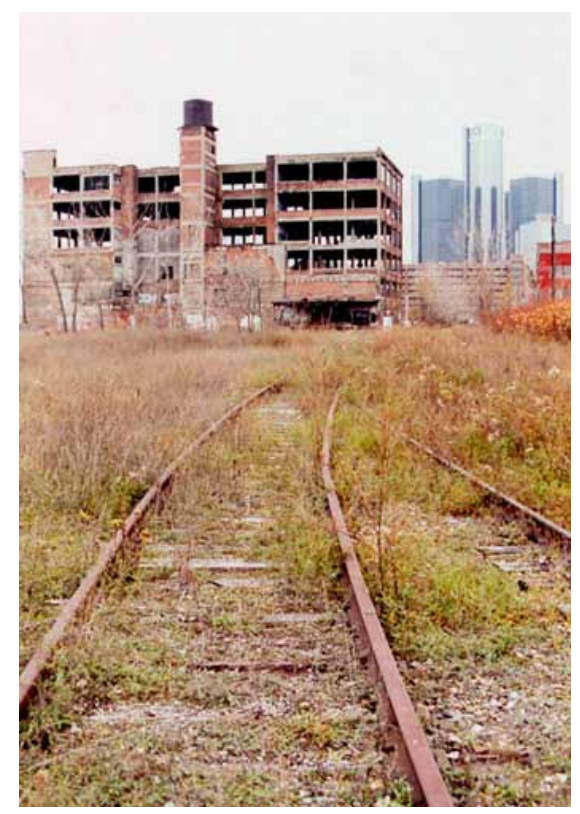

Fig. 1. Derelict warehouse with Renaissance Center beyond showcases the city's economic disparity (Source: Scott Hocking) 


\section{Introduction}

Detroit's story as one of economic struggle and racial division is well-known and publicized. The story recently added a new chapter as national and international attention renewed when the car manufacturers faced bankruptcy that resulted in a number of controversial federal buyouts. The attention generating phenomenon known as ruin porn, has been fueled in part by photographers such as Camilio Jose Vergara (see Fig. 1 for an example of the type of photographs circulating the global media). The photographs provide a safe vantage point for the global spectator to follow Detroit's ruination. An explanation of Detroit's decline from car manufacturer mecca is commonly portrayed as a series of economic woes further complicated by extreme racial division. This paper provides an alternative narrative discussing other forces at play, with a focus on questionable moral standing and its relationship to built form, specifically the city. ${ }^{2}$ The paper will explore whether a compelling claim on building's moral use can be established, and in doing so it will seek to establish a causal link between moral relationship and the built environment. Moral relationship will be established through three main avenues. The first is a brief discussion of Detroit's history, particularly its history from WWII onward, in order to establish the complex moral context into which this argument is situated. This analysis relies heavily on Thomas Sugrue's seminal text The Origins of the Urban Crisis because the analysis and content is uniquely well situated for making moral arguments, as Sugrue highlights not just what was done but what could have been done. The second avenue provides a concise summary of Stanley Cavell's moral framework as presented in his seminal 1979 text The Claim of Reason and discusses the conundrum of having moral obligation without moral relationship. The final avenue is a look to the famous Renaissance Center as emblematic of the moral relationship at play. While this analysis does not negate the role of economics and race in Detroit's story, it does seek to add moral questions largely undealt with in popular accounts. Making this analysis not just an original contribution to understanding morality in architecture and urbanism, but an original contribution to the story of Detroit's decline.

\section{Boundaries of Morality}

Despite popular attributions of Detroit's urban deterioration and negligence as caused by the decline of the auto industry are in combination with extreme racial tension - both of which certainly did negatively impact the socio-cultural environment - urban historians, sociologists, and political scientists tell a much different story of Detroit's decline (Romney 2008: A35; Maynard, Blunkley 2008: B1; Hackman 2014). ${ }^{3}$ Amongst the key points the popular accounts overlook is that Detroit has been in decline since at least 1950, and there is no direct correlation between racial tensions, namely the race riots, in affecting the population decline (as is evidenced by the U.S. Census records). Yet, there is a strong correlation between job loss and population decline, likely due to the highly centralized economy (Sugrue 1996).

The post-war economy was centered on car manufacturing, serving as the largest national producer of cars. The removal of corporate obligations to employees and locale as well as the introduction of new trade boundaries restructured the economy creating no need or desire for highly concentrated manufacturing. Thus it appears the major population declines were caused by war and changes in economic structures. The first population dip occurred in the early 1940s with the drafting of soldiers for WWII. The Vietnam War had a similar effect in the 1960s, but was compounded by the deunionization of corporate employees and growing suburbanization (U.S. Census). ${ }^{4}$ More recently in the late 1990s and 2000s, neoliberal's 1994 North American Free Trade Agreement (NAFTA) decimated Detroit and the Rust Belt region's economy as it gave the right to trade freely within a large geographic area, effectively restructuring the local economies through the region and dispersing former concentrations, such as Detroit.

Definitive amongst urban historical accounts of Detroit, Thomas Sugrue's The Origins of the Urban Crisis, provides a detailed analysis depicting Detroit's elected and appointed officials as holding key responsibility for the declining appearance and functionality of the city's buildings and infrastructure. The actions underpinning the decline, as Sugrue demonstrates, can be found in the formation of critical public policies. The painstaking detail Sugrue provides, echoes many of the patterns also accounted for in the 1968 report, also known as the Kerner Report. ${ }^{5}$ Sugure's analysis differs from the report in that it focuses on the particular history of Detroit. Sugrue ultimately does not establish the fairly obvious symptoms of poverty, but rather works to undercover the causes. For Sugrue one of the major causes is the systematic isolation of minority groups from local, state, and federal support whether in the form of democratic representation or direct subsidies such as Federal Housing Act (FHA) loans, both readily made use of by mainstream groups.

The alternative narrative of Detroit's urban history begins with democratic representation. Detroit's political structure was insufficiently stratified to represent 
the different groups present within the city, which precluded the already marginalized groups from partaking in "decisions having community-wide effect" (Marger 1979: 343). The lack of democratic representation precluded marginalized groups not only from having a policy-based relationship with the city that could benefit them; it precluded them from protecting their rights and promoting their interests as citizens. Those that did have such a relationship fully utilized its power to their personal advantage at the exclusion of others.

The majority developed a compelling ideological position supporting their group's specific socio-economic interests. The majority wanted to secure their own economic progress as well as their idea of good society. As a group, they were well-organized, articulate and ultimately effective in getting what they wanted. Sugrue briefly describes the generation: "In reaction to the economic and racial transformation of the city, Detroit's whites began fashioning a politics of defensive localism that focused on threats to property and neighborhood" (Sugrue 1996: 210). The majority drew on defensive localism, or exclusionary practices, to justify decision-making across the city. Most notably, such decisions included building neither housing - as recommended by experts in the midst of a known housing shortage - nor implementing other potentially useful public policies designed to address the growing housing crisis within the city (Sugrue 1996).

The severe economic marginalization of African Americans meant that they struggled to find equal opportunity in education, employment, and housing. In many instances, the economic obstacles manifested as explicit racism. Employers hired African Americans less frequently or not at all. When employers did hire African Americans, the positions were usually the lowest ranking, independent of knowledge, skill, or incumbency. Furthermore, education remained legally segregated until 1955, after the Brown v. Board of Education case, yet at the same time, the cost of university tuition remained prohibitive for most. Implicit racism, or institutionalized racism, was increasingly relied upon as overt racism became illegal or increasingly socially unacceptable. In the case of housing, the 1934 FHA policy was a progressive act to help middle and working class Americans secure a place on the housing ladder as never before. The act provided subsidies and access to affordable mortgages that allowed many Americans to purchase homes that would not otherwise have access to. The loans were a critical component in the post war housing boom. Yet, the federal loans were largely inaccessible for African Americans to secure, because banks and realtors remained un- trusting of the African American community (Sugrue 1996; Kanner 2013). Practices such as redlining insured unequal access to funds. Thus, African Americans remained barricaded behind invisible administrative and institutional walls, as opposed to the barriers of legislated segregation and slavery.

The African American struggle to secure an income meant they could not simultaneously seek out the training necessary to seek out better employment options. Doubly, the people could not access federal assistance to secure mortgages for adequate housing. In cases when all these obstacles were overcome, the people faced fierce local opposition to homeownership in white working-class and middle-class neighborhoods. Preclusion from economic opportunity robbed an entire population of not just economic mobility but economic ability. The result was catastrophic, as the African American populations in Detroit suffered widespread economic deprivation resulting in decades long community blight. Cities across the country faced the same effects of FHA loans and the discriminatory practices of its administration, but Detroit seems to have suffered most severely due to inaccessible housing loans and a combination of other less significant factors (Gordon 2005).

The lack of unequal access to education, employment, and housing often manifested most clearly in unequal access to urban space. African Americans were precluded from freely participating in the housing market, which prevented them from living in the same neighborhoods, attending the same community and civic venues, and obtaining access to the same services and amenities. The restrictions manifested themselves quite clearly as neighborhoods were self-segregating, and although the population of the city continued to decline, the city's demographic majority became African American. Perhaps the clearest manifestation of unequal access to urban space is illustrated in Figure 2, which shows the majority white population on one side of the famous 8 Mile road, and the majority African American on the other. The 8 Mile road became the physical representation of hypersegregation between the white and black neighborhoods, becoming so culturally entrenched in the psyche of Detroiters that songs, such as Eminem's 8 Mile, were written about the role this road plays in the cultural landscape of the city. Interestingly enough, the socio-cultural organization on either side of this road results in physical implications, as the two sides are physically quite different. In any case, that the socio-cultural and geographic configuration exists is well-known and documented, but that it can largely be attributed to the inability of African Americans to fully participate in the economy and housing market is not. ${ }^{6}$ 


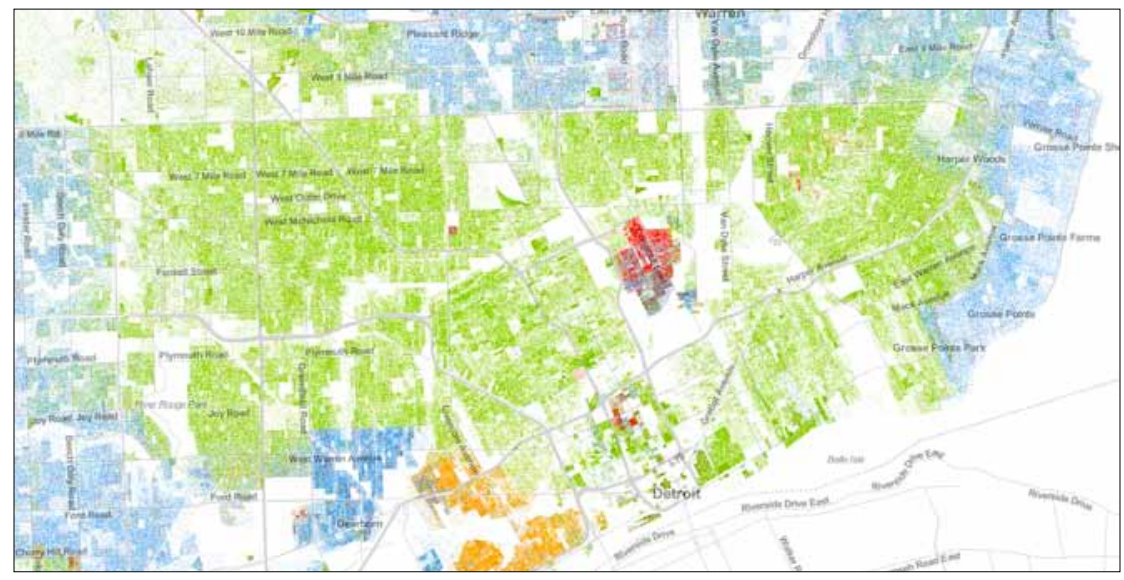

Fig. 2. Present day residences across the city by racial distribution reveals stark boundaries between white and African American as well as a marked lack of white residents overall. Blue dots indicate white residents and green African American. (Source: Dustin Cable, Demographics Research Group Weldon Center for Public Service, University of Virginia).

Perhaps the most visually apparent complication of Detroit's development pertains to the affordable housing shortage documented by sociologists, political scientists, and economists. Already in 1942, Detroit had been struggling to keep up with the demands of a rapidly growing population and address the consequences of its effects (Woodford 1942: E10). The city's housing demand was high during the height of the manufacturing booms, which caused a corollary population boom - roughly from 1940 to the early 1950s (see Table 1). As a result, public services were stretched and housing and planning policies were illequipped to deal with the quickly changing social demands. The city suffered from managerial retardants, such as inadequate land use and zoning policies unable, for instance, to prevent residential areas from rapidly turning into business districts (Marger 1979). The city's population and economic growth created residential districts overrun by new business districts and land use was that rapidly shifting (Marger 1979). Of particular interest is the city's inability to mitigate the growing housing shortage (Sugrue 1996; Kanner 2013).

Key in Detroit's alternative narrative is the city planning and management's lack of response to the changing city, which this paper argues brings the status of moral relationship critically into question. Clearly documented evidence shows that the city's officials and administrators actively refused opportunities to respond to changing needs and demands of its population (Woodford 1942: E10; Seigel 1997: A5). Without democratic representation of the city's marginalized minorities and poor (often the same groups), proposed projects and policies responding to growing housing demands were not adopted or otherwise implemented. The proposed building projects and policies were in- tended to stave off the spread of poverty, but there was direct opposition. Sugrue attests that:

In cities like Detroit, social reformers and federal officials fought to erect public housing sufficient to meet the needs of those whom the market failed to serve. But public housing advocates were repeatedly stymied by homeowners who asserted their own interpretations of New Deal social policy. They demanded that the government privilege [sic] the stability of their ownership, over and above its support for public housing (Sugrue 1996: 59).

Staunch in their belief that their intentions were good, the manifestation of defensive localism fortified a steadfast institutional wall preventing African Americans access to housing and the most fundamental element of individual economic stability within American society. Although admittedly housing itself could not have wholly solved perennially high unemployment rates, housing options would have stabilized living conditions for the poor, thereby reducing the depths of urban decay that came with social neglect and abandonment (McDougall 1987: 741-742). Housing inaccessibility acted as a strong and direct force enacting on the physical shaping of Detroit.

The government led initiatives to renew urban centers via the Housing Acts of 1934, 1949, 1954, and 1959. The program implemented an idealized, context-less development program known as urban renewal that was founded on the belief that simply removing blighted areas would solve the problem of decay. In this regard, urban renewal fundamentally operates on a belief in physical determinism, in that the physical removal of buildings was thought to solve the social 
Table 1. Social, economic, and political influence on Detroit

\begin{tabular}{|c|c|c|c|c|c|c|}
\hline \multicolumn{2}{|c|}{ Political leadership } & \multicolumn{3}{|c|}{ Census data } & \multicolumn{2}{|c|}{ Potentially significant events } \\
\hline President & Presidency & Date & Population & Difference & Detroit & Nation \\
\hline Roosevelt (R) & 1901-1909 & 1900 & 285,704 & $+180,062$ & & \\
\hline Taft (R) & 1909-1913 & 1910 & 465,766 & $+527,912$ & & WWI (1914-1918) \\
\hline Wilson (D) & 1913-1921 & & & & & \\
\hline Harding (R) & 1921-1923 & 1920 & 993,678 & $+574,984$ & & \\
\hline Collidge (R) & 1923-1929 & & & & & 1929 Stock Market Crash \\
\hline Hoover (R) & 1929-1933 & 1930 & $1,588,662$ & $+54,790$ & & $\begin{array}{l}\text { Great Depression (circa 1930- } \\
\text { 1945); New Deal (1933-1936) }\end{array}$ \\
\hline Roosevelt (D) & 1933-1945 & & & & & $\begin{array}{c}\text { WWII (1941-1945); 2ND Red Scare } \\
\text { (1947-1954) }\end{array}$ \\
\hline Truman (D) & 1945-1953 & 1940 & $1,623,452$ & $+226,116$ & Race Riots (1943) & \\
\hline Eisenhower (R) & 1953-1961 & 1950 & $1,849,568$ & $-179,424$ & & Civil Rights Movement (1954-1966) \\
\hline Kennedy (D) & 1961-1963 & 1960 & $1,670,144$ & $-156,081$ & & Civil Rights Movement (1954-1966) \\
\hline Johnson (D) & 1963-1969 & & & & Race Riots (1967) & Civil Rights Movement (1954-1966) \\
\hline Nixon (R) & 1969-1974 & 1970 & $1,514,063$ & $-310,695$ & & \\
\hline Ford (R) & 1974-1977 & & & & & \\
\hline Carter (D) & 1977-1981 & & & & & \\
\hline Reagan (R) & 1981-1989 & 1980 & $1,203,368$ & $-175,389$ & & Economic Recession (1980-1982) \\
\hline H.W. Bush (R) & 1989-1993 & & & & & Iraq war \\
\hline Clinton (D) & 1993-2009 & 1990 & $1,027,974$ & $-79,704$ & & $\begin{array}{c}\text { North American Free Trade } \\
\text { Agreement (1994) }\end{array}$ \\
\hline G.W. Bush (R) & $2001-2009$ & 2000 & 951,270 & $-237,493$ & & $\begin{array}{c}\text { Housing Market Bubble } \\
\text { (2002-2009); } \\
\text { Stock Market Crash (2008-2009) }\end{array}$ \\
\hline \multirow[t]{2}{*}{ Obama (D) } & 2009-2017 & 2012 & $713,777^{*}$ & $-12,302^{*}$ & $\begin{array}{l}\text { General Motors } \\
\text { Bailout (2009); }\end{array}$ & \\
\hline & & 2013 & $688,701^{*}$ & $-25,076^{*}$ & $\begin{array}{c}\text { Chapter } 9 \\
\text { Bankruptcy (2013) }\end{array}$ & \\
\hline
\end{tabular}

*estimated populations

(Source: Population adapted from United States Census Bureau - www.uscensus.gov.)

problems they displayed. Whether one believes in physical or environmental determinism in practice, the program's apathy toward the lives of those affected by the policies was explicit, and the effects on the wider City of Detroit unambiguously negative.

The Kerner Report reports that urban renewal "has demolished more housing than it has erected" (1968: 480). Since the rate at which housing was removed from the housing market exceeded any effort to rebuild, the federal program enacted to address housing conditions simply exacerbated the already desperate situation of those in need of housing. The report acknowledges that urban renewal initiatives were often merely displacing residents of blighted areas, but argues, "we believe that a greatly expanded re-oriented urban renewal program is necessary to the health of our cities" ([emphasis added] Kerner et. al. 1968: 480), regardless of the fact that there was no provision for dealing with the people displaced by the renewal programs. This trend of removing housing without providing or at minimum planning for an alternative means continued on for decades. One citizen remarked as late as 1997 that she was "unhappy with the demolition of public housing because it left low income people with nowhere to go" (Seigel 1997: A5).

The lack of democratic representation, housing shortage due to population increase, and systematic demolition of unsightly housing precluded the possibility of sustainable life for the economically and racially disadvantaged. But these factors also tell us what the moral relationship of the city's officials to its most socially vulnerable and economically insecure was: they were certain they did not have the resources available to help the under or poorly housed, but they did demolish existing housing. At times explicit displacement of 
responsibility occurred as African Americans were held wholly responsible for their situation: "To white Detroiters, the wretched conditions in Paradise Valley and other poor African American neighborhoods were the fault of irresponsible blacks, not greedy landlords or neglectful city officials" (Sugrue 1996: 216). The judgment-laden views of the poverty-ridden blacks effectively dismissed others of any potential responsibility for the state or condition of the other (Wacquant 1997). In order to have taken the marginalized people's position into account, the city - both its officials and residents would have had to operate with a more inclusive or representative notion of the public and public interest, a specific instance of which would have required effectively addressing the housing shortage. By position, the city officials held the responsibility to act in the public's best interest. Yet as Sugrue shows, the city officials had a number of opportunities to take different courses of action on affordable housing and unemployment but actively chose otherwise due to ideological positions as opposed to nonnegotiable barriers.

The characterization above depicts a widespread preclusion of moral relationship, because the basic foundations required for moral relationship, as defined by Cavell, were non-existent or inoperative. ${ }^{7}$ In order to recognize the other and take into account their position at all, there were certain moral obligations that would have to be upheld. Addressing the housing shortage with practical and effective solutions through the administration of policies and legislation and administrate a program to reduce the disparity of resource inequality apparent in the city would have been a requirement of upholding moral obligation. Instead, what little inner city affordable housing there was was razed. Meanwhile those able to secure FHA loans were buying homes in the new suburban developments outside the city, thereby taking with them any possibility of supporting an inner city economy that could support the poor or otherwise stave off the onset of widespread poverty. Their movement to the suburbs was the budding residential ideal of the latter half of the $20^{\text {th }}$ century. In this configuration, in which whites are able to leave the city (a.k.a. the white flight), those that remained behind in the city were largely African American (Kerner et al. 1968; McDougall 1987; Sugrue 1996). The result is the racial ghetto bluntly described in the Kerner Report (1968: 236), not as a result of race and economy, but rather of neglect and abandonment.

\section{Un-acknowledgement}

The lack of democratic representation in combination with an affordable housing shortage and active hous- ing stock reductions led to a struggle for subsistence that was dealt with outside the mechanisms of modern democracy. ${ }^{8}$ The public fora, or formalized democratic processes of the city, state and nation, did not address the lack of democratic representation, the affordable housing shortage, or the reductions of existing housing stock. The result was competition between the white working class and African Americans of all socio-economic strata to secure their standing in the housing and job markets. The outcome features amongst the first instances in which whites were in direct competition for the same resources as African Americans, in the sense that whites and blacks had not previously been in direct competition for the same jobs, housing, schools, and other essential resources. The subsequent denial, in that there was unequal access to these resources, suggests that forces were at play keeping African Americans from securing equal access.

The promises made in the New Deal, begun in the early $20^{\text {th }}$ century, raised hopes and aspirations of all Americans, and the civil rights movement raises the expectations of African Americans to take an equal part of the federal government's promise to all its citizens. The deal was generally a response to the Great Depression that was intended to both lift people out of poverty and prevent another major economic depression. The response included a large bank bail out, increased market securities, and investments in social programs, such as social security, government employment, and minimum working standards including minimum wages and maximum hours. The national mood of entitlement and aspiration "created a sense of crisis among [white] homeowners. Both their economic interests and their communal identities were threatened," by the presence of African Americans in their neighborhoods and thereby their community (Sugrue 1996: 214). The crisis manifested in creating self-segregated neighborhoods and city abandonment, or the white flight, in favor of the exclusivity of the growing suburbs.

In an effort to define the self-identity of the two groups, a sociological study subsequently examined the aspirations of Detroit's suburban whites helping to clarify the point of contestation. The study provides two theories for describing the compelling-ness of the suburbs over the city: "One theory argues that suburbs are vast shifting and sorting units in which the White middle-class person chooses a community that fits his values and life goals. Another theory argues for the changes which persons undergo once they come into the social world of a given community" (Marger 1979: 337). In either, the case of selection or of socialization, "[Whites] fail to realize that the blacks who enter their 
neighborhoods would resemble them in [both] social and economic standing" (Marger 1979: 109). Similarly, contemporary political historian and theorist Danielle Allen discusses the reoccurring powerful rhetorical device of oneness in the political realm. She draws our attention to the role the concept of unification and oneness played in the America's history, focusing on how oneness was used in the context of school segregation, and raises the question as to whether, "the rhetoric [was] supposed to unify, once again, Southern and Northern whites, or was it at last to unify white and black?" (Allen 2009: 15). The lack of recognition or the lack of oneness, amounts to a kind of disinterestedness serving to (self)justify the actions of moral autonomy from the other. The autonomy serves to uphold a particular form of community - a community that insulates itself, not just from the physical intrusion of perceived outsiders but, from the most basic moral concerns directed at and emanating from such outsiders. Thus, the refusal of the white community to recognize themselves in the other, or the refusal of a black and white oneness, is a core operative factor in the shaping of Detroit's urban story through the latter half of the $20^{\text {th }}$ century.

Questions of democratic representation, an ideologically induced affordable housing shortage, together with evidence of actively not building housing and turning down opportunities to build it are not just practical oversights and shortcomings. There is activity to address the presence of the ghettos through urban renewal, effectively just reducing ever more the low-income housing supply in the midst of a huge affordable housing shortage. Understanding the cumulative effects of the general state of things - in terms of democratic representation, ideological marginalization, employment access, housing access, little tangible response by the city, and federal urban renewal initiatives - quite clearly accounts for the resulting abandonment and self-segregation of the city. Yet, the question must be raised: why was there no direct and concerted effort to help reduce the breadth and depth of poverty in the city? Would such a lack of engagement with the poor absolve one of moral obligation to the poor?

\section{Cavell's moral contradiction in use}

In an effort to delineate where morality and moral responsibility lies, the analysis looks to the moral philosophy of Stanley Cavell. Cavell's moral account provides a conceptual framework for theorizing in what capacity buildings, and by extension larger segments of the built environment, can hold moral use. To begin with, the term use remains distinct from the term function often used with widely varied mean- ings in architecture's Modernist discourse. Rather it is here used in the distinctly Wittgensteinian sense. Wittgenstein states in the Philosophical Investigations "the meaning of a word is its use in the language," leading us to infer that meaning is defined as use, which is to say, use is meaning (Wittgenstein 1951: $\$ 43)$. In application, what counts as use becomes the focus of investigation. In the context of architecture and its potential morality, the remark suggests that if buildings have use they have meaning. To locate buildings' meaning we must first understand their use. Use, in this analysis, is not limited to the debates of architectural functionalism, which pertain to the development of a building aesthetic as opposed to a kind of forensic investigation. Whilst the investigative framework is potentially clarifying of many other mischaracterizations of architecture, it more significantly reveals instances in which use indicates moral use. In other words, if there is moral use there is moral meaning, and similarly if there is moral meaning there is moral use. The goal in establishing cases in which buildings can be shown as having moral use, is to determine whether they may serve further as a conduit of moral relationship. Thus, the outstanding question in this analysis is precisely how buildings are moral, which is to say for which uses buildings are taken as moral. ${ }^{9}$ Because if use can be located, its corollary meaning - is too. But first, let us establish more firmly what is here, and subsequently, meant by moral and moral relationship.

Morality demands acceptance and mutual understanding, as Cavell argues in The Claim of Reason. He writes, "one human being confronts another in terms of that person's position, and in a mode which acknowledges the relation he is taking towards it," setting the first criterion of moral relationship in epistemological terms (Cavell 1979: 325). Acknowledging requires an understanding of the other's position and an understanding of both the position one is coming from and the mode in which one engages. The second criterion establishes which actions count as morally motivated, or that, "what is required in confronting another person is not your liking him or her but you being willing, from whatever cause, to take his or her position into account, and bear the consequences" (Cavell 1979: 326). Cavell's point is that there is no possibility of moral relationship, that there cannot be moral relationship without some knowledge of the other. Knowing requires, for instance, at least some understanding of the person's socio-cultural context, especially their values and belief systems, which is to say a kind of engagement with the other. Thus moral relationship is defined in part as knowing the other. 
However, it is not to say that if there is no engagement, morality is by definition precluded. One can still act in such a way that one may consider moral without engagement, however one cannot have held prior moral intent nor moral relationship. Furthermore, engagement alone does not guarantee morality, for one can be in dialogue with another and act immorally or amorally. Instead, knowing establishes the boundaries of moral appraisal, but is not equated with moral action.

It is this aspect of morality in architecture that seems often overlooked in favor of moral appreciation or evaluation, yet moral relationship is both integral and critical to the building process. Taking another's position into account and bearing the consequences of doing so is effectively what developers, architects, planners, city managers and other key stakeholders do, or at least ought to do when they set out to create a building or revitalize a neighborhood. It is their responsibility as built environment professionals to both know and respond to the socio-political climate in which the other operates. It is not just their responsibility within the codes of professional ethics, but their moral responsibility as individuals participant in the relevant socio-cultural context. ${ }^{10}$

The third key criterion of moral relationship as accounted for by Cavell is agreement. Cavell professes:

To the extent that responsibility is the subject of moral argument, what makes moral argument rational is not the assumption that there is in every situation one thing which ought to be done and that this may be known, nor the assumption we can always come to agreement about what ought to be done on the basis of rational methods (Cavell 1979: 312).

Instead of mindlessly guiding our actions according to principles, theses and doctrines, we are left to get to know ourselves and one another to decipher what is appropriate action. The statement dismantles the assumptions underpinning our universals, leading us to fall back on knowledge in a renewed sense. In doing so, the third criterion supports the first two by creating a mutual dependence between knowledge and acknowledgement. Cavell states:

[Moral argument's] rationality lies in following the methods which lead to a knowledge of our own position, of where we stand; in short, to a knowledge and definition of ourselves (Cavell 1979: 312).

In this reality, agreement plays a critical role, suggesting not only is there a kind of mutual understanding required for the possibility of moral relationship, but that knowing oneself occurs in relationship to another, in the sense that we derive an understanding of ourselves as a result of identifying how we differ from another. The ability to relate then rests on the understanding of self and other, without which the ability to secure agreement is precluded.

\section{In use}

Regarding cities and buildings, there are an infinite number of actions taken that implicitly, explicitly, tacitly, or overtly require knowing and agreement. The practice of building is itself a process based on a series of agreements (Wittgenstein 1951: \$241-242). ${ }^{11}$ Some of the agreements predate the individuals enacting them, such as use of certain materials, the particular compositional configuration of a floor plan, or a predefined decision-making process. Predating agreements may also describe building's tradition and its conventions. ${ }^{12}$ For instance, the conventions of drawing a series of plans, sections and elevations communicating the building's construction are based in prior agreement about the way of doing things. We could communicate building plans in languages, or through a series of detail drawings along with a largescale model. That we have chosen to use drawings in the way that we do is partly because of our collectively having done so, but certainly not entirely because it is objectively the most practical, obvious or only way of communicating the building plan. Along a similar vein, the particular tradition of placing a dedication stone on public buildings, which details the project date and key stakeholders in the building's construction, is also an agreement about the way of doing things. The practice signals a valuing of the Western calendar and attribution of powerful patrons, but it is not a universal practice - not within Occidental culture, and certainly not across global cultures.

While there are many more types of agreement related to building than can be accounted for here, such agreements establish what we do, which positions we respond to, take into account and bear the consequences of. Agreement determines:

the way in which the arena and court of play marks off what will count as our responsibility and our concerns. The problems of morality then become which values we are to honor and create, and which responsibilities we must accept, and which we have, in our conduct, and by our position incurred (Cavell 1979: 325).

The question then is what counts as the city's concern within the general boundaries of moral relationship sketched out above? 


\section{Moral contradiction in use}

The concern within the general boundaries of the city's moral relationship appears to be its self-defined moral intent and a broader overarching idea of moral relationship as defined by its citizens. ${ }^{13}$ An indication of the public moral stance is captures in the 1955 Spirit of Detroit statue. The statue figures prominently in the consciousness of the citizenry, and is often attributed as the symbol of Detroit. It's inscription is the morally upstanding statement "Now the Lord is that spirit, and where the spirit of the Lord is, there is liberty," which describes the beliefs, attitudes and value systems of the city as an institution and the people that inhabit it. Yet, liberty broadly construed seems to have been lacking in the portrayal of restricted participation in the economic and housing market. Taking the inscription as an implied indication of the city's moral stance, did it uphold its own values? And did it meet the expectations of the citizenry who also held these values? We can never know absolutely, but an appraisal of the city's relationship to all its citizens can be proffered. One building, it is argued is particularly revealing.

Amongst the most pronounced examples of the disparity is the Renaissance Center, a commercial complex built on the Detroit riverfront in 1977 (see Fig 3). The center, colloquially known as the Ren Cen, was promoted for its potential to solve the problems of poverty and economic decline in Detroit by economic effect.
Privately financed by investors and through fundraising events organized by heir of the Ford Company, the Renaissance Center was a significant private undertaking. ${ }^{14}$ The desired effect to generate local capital was assumed to indirectly generate the broader and more comprehensive economic stimulation so desperately needed. The belief was that a better economy would in itself solve the city's festering social problems rooted in chronic unemployment and catapult the city back to national and international significance. Promoting the project, Mayor Coleman Young is quoted as saying, "the entire world will see that Detroit, which was once declared dead, is indeed alive and well and that we have recovered from the maladies of our part" (Stuart 1979a: A10). Given this and similar claims, the building was presented as a partial solution to Detroit's economic woes.

The economic trickle down model was widely supported, particularly by the politically conservative acolytes of Ronald Reagan. In some regards, the economic model worked as there were some successes in stimulating economic growth. Washington Boulevard was renovated, and further investments were made in other parts of the city by the General Motors Company (Stuart 1978: A18; Stuart 1979a: A10; Stuart 1979b: A20). Yet, the project failed to meet the optimistic economic ambitions of the developers, investors, and the city, or otherwise serve as an impetus for others.

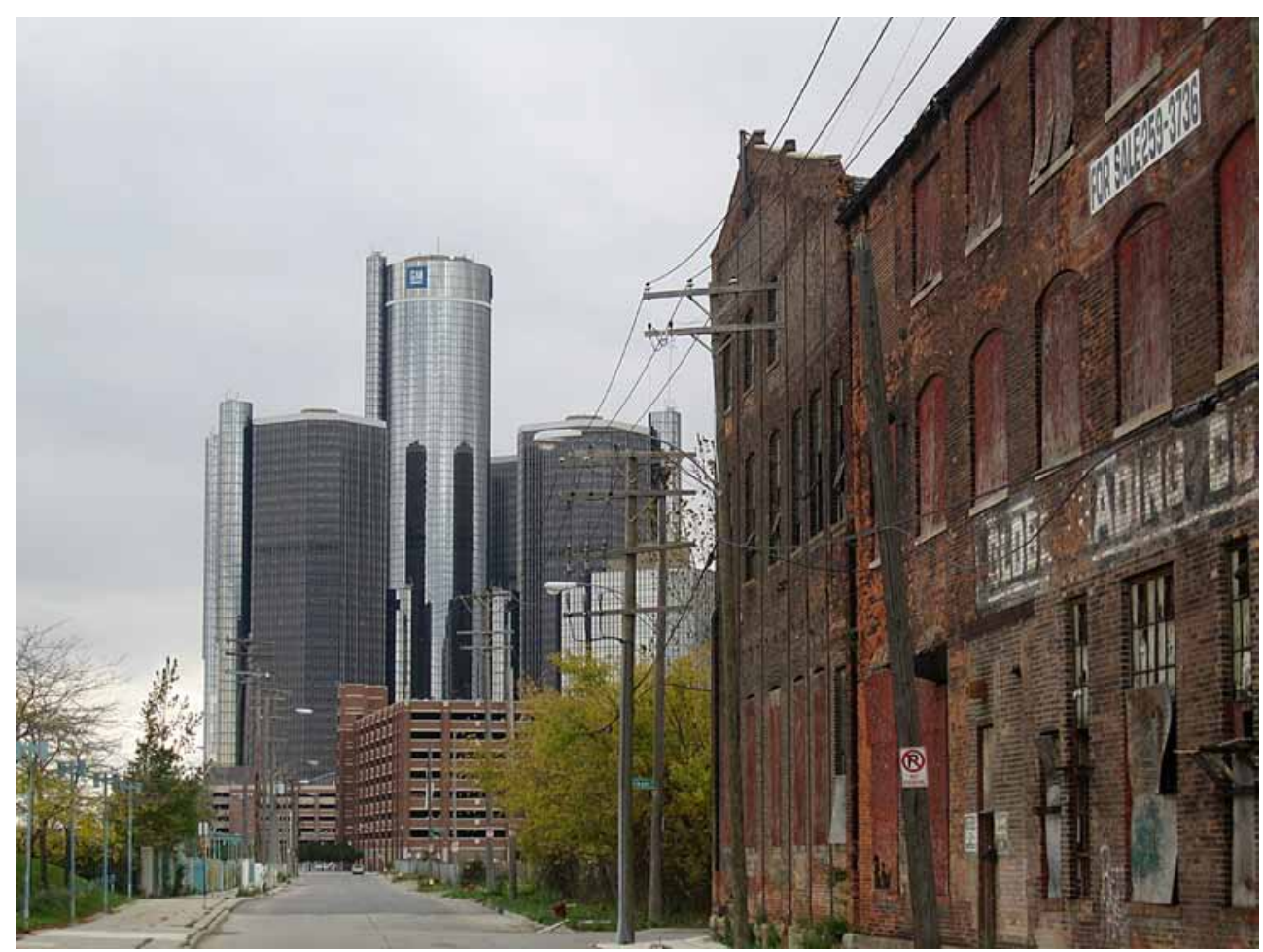

Fig. 3. Juxtaposition of a warehouse house with the Renaissance Center's luxury hotel and conference center (Source: Philip Hall) 
Shortly after the completion of the project, complaints were reported that:

the center has "stolen" tenants from other downtown buildings [...]. The result is a daytime shift of activity across downtown, with the action moving toward the southeast corner toward the river where the Renaissance Center is located [... Thus the development] merely rearranged what downtown activity already existed (Stevens 1977).

New investments, businesses, and jobs had not been created by the mere presence of the building within the city, resulting in the general sentiment that the project had not lived up to its promises. Time has shown that the economic upturn sought after did not come.

The building itself is sited in such a way that isolates it from the city. Jefferson Avenue sits between the edge of downtown and the building's entrance, occupying approximately three hundred feet in width, or the length of an American football field. The avenue is broad enough to allow for three lanes of traffic in either direction, with wide sidewalks and shoulders, as well as amply planted medians. The sheer size of the road, in combination with the relatively high speed of traffic, creates a significant barrier between the downtown and the Renaissance Center. On the other side of the Renaissance Center is the riverfront of the Hudson River. Since there is little or no development on either side of the project, its placement was effectively like an island accessible only by car from roads quickly leading out of the city into the posh northeastern suburbs or to Ann Arbor to the west. Given the site plan's spatial composition and the project's physical isolation, there is little possibility for relationship with the rest of the city. Architectural critic Paul Goldberger's reading is similar, stating that the building, "sets itself apart from Detroit, so dramatically that one almost feels compelled to question the developer's assertion that the project represents a 'vote of confidence' in the city" (Goldberger 1977: 16).

The site plan is not the only point at which the building's spatial composition reveals the intended isolation from the city's public. ${ }^{15}$ The building was not originally intended for public use, but rather for hosting the business and political elite. Whilst the commercial programming of the space may seem a practical solution, particularly given the economic aspirations of the project, the planning for an abundant amount of office and hotel space in an increasingly unpopulated city seems unnecessary if not excessive. The apparent excess is only exaggerated when considering both the low-income housing shortage and the redundancy of building type within the downtown area, particularly in light of the downtown vacancy rate. Further, the building itself allowed limited public access, to lobby spaces only and where fine attire was a strictly held entry requirement. Given the planned use and configuration of the spaces, there was evidently no intention to inclusively engage the public. The building provided space only to those in the socio-economic strata that were able to afford the fine attire required for entry.

The idea that the investors and city officials meant to do nothing about the situation in Detroit is not an accurate description. However, what the key decision makers intended to do, in the case of the Renaissance Center, displays a superficial understanding of the problems faced and a primarily self-interested motivation (because of potential economic benefits). While it is impossible to ever conclusively know whether the project would have been successful had it embraced the reality of the city's moral context instead of isolating itself to address the concerns that appeared most suited to their (economic) interests, what is clear is a moral contradiction in the promotion of the project to the city's residents. The politicians and private stakeholders claimed the building would help everyone and create for everyone a better city by helping to create a better economy for everyone.

The stakeholders' claim about the impact the building would have on the city and its people may not have had discernable moral intent but it certainly can be morally appraised. On the one hand the private stakeholders of the Renaissance Center take a morally isolated position (in that the project explicitly does not directly address in use or otherwise engage the societal problems within the city) and yet at the same time continues to make public moral appeals to the same people whose concerns they have already opted not to concern themselves with. The discrepancy is itself concerning, and the question must be raised as to whether the stakeholders could have garnered the public support necessary without fallacious moral arguments appealing to the greater public good. What is clear looking at the socio-political context is that they could not have achieved the public support for the project without the appeals to the greater public good, as public opposition could have halted the project through planning commission and city council, as well as damaged the public image of corporate financers. Furthermore, it is unclear whether the building's stated intent was not just a political statement to appease locals, or whether the statement was something that they themselves intended to uphold, hence the apparent fallaciousness of the claim.

It is of course possible that the project had greater meaning for the city than simple economic 
regeneration. The building may have served more as a beacon of hope for the future, for faith in achieving a new and better future. There is evidence to suggest as much is true. Within a year of the project's completion, a survey was conducted on residents' perceptions of city, in which:

city suburban, black and white residents were expressing greater faith in the city's future than they did in 1976 and 1977. Only 47 percent of those polled in 1976 felt optimistic about the city [...] Today, the percentage has rise to 71 percent. Relations between the city police force and residents are viewed more positively, but confidence in public schools continues to slip. [paragraph] The greatest confidence $[\ldots]$ was among lower-income adults, upper-income blacks and black homeowners. Those who were found to be most pessimistic were residents of the suburbs, upper-income whites and suburban homeowners (Stuart 1978: A18).

The results show that city and area residents remained divided, but that those who served to benefit the most from a renewed city were also the most optimistic about its potential effects. Perhaps it was that the suburban residents, who were more economically able, remained skeptical preventing them from providing the critical support necessary for the new project to survive. As it was though, the building could be meaningfully held as a symbol of sorts to the inner city residents of Detroit for future opportunity, as it served as a visual reminder that the building itself failed to deliver its promises.

Given the criteria for moral relationship, the basic mapping of relationships, what use - moral use - can the Renaissance Center hold?

Although the stated intentions may superficially be taken as morally upstanding, the intentions are testament to the lack of understanding and lack of relationship between the city and city officials to its people. This is evidenced by the lack of response to the peoples' precise needs and circumstances. Ford and his investors may have taken up the project out of a generally good moral sense, but the execution and underlying motivations are directly linked to an individualized sense of individual gain, not a shared one. This is not to say that moral relationship is only possible when no one benefits from the relationship in question, but rather that an individual's personal benefit is not the basis for relationship.

It appears as though the individual interests of the project's stakeholders were the only directly engaged during in the conception of the Renaissance Center.
Taking this as the case, the building's stated moral intent is reasonably sound only insofar as an elitist understanding is able to capture the cares and concerns of the urban poor. That the stakeholders did not meaningfully consider the broader public interest may go someway to explaining why they were not able to achieve the project's implied social objectives or its moral purpose. Buildings depend on people to give them use, to give them meaning. Without engaging the people, and without giving them a means of engaging it, it is no surprise that the building quickly found itself without strong local support.

The precise socio-cultural circumstances in Detroit - whether good or bad - were not engaged, making it difficult to understand how a project as ambitious as the Renaissance Center could have reached the lofty goals believed. As it was, the project was conceived from the perspective of the economic elite, which is to say, one that in this regard was not engaged with the circumstances of the urban poor. Thus, the building's stated moral intent was reasonably sound only insofar as the economic and political elite's understanding was able to capture the cares and concerns of the urban poor. The project claimed to solve the city's social problems oddly enough through pure economic initiatives divorced from any social or political initiative aimed to directly respond to, or even acknowledge as worthy of recognition, the needs of the citizens.

There was no clear intent of helping the urban poor, particularly the economically underprivileged and African Americans, but rather there appears to have been an aim to mold the city into what a city ought to be socio-economically: a burgeoning economic hub bustling with the business activity the investors profit from. If the building's intentions are understood as economically motivated, on the basis of a trickle down model, the moral intention is at best suspect. As such, Ford's initiative may have appeared to have good intentions, but remained incapable of success because of a lack of genuine or substantial engagement with the problems it was intended to solve. The failure to meet its presented moral intentions was and remains an indication of the disparity between the building's intended or claimed moral use and the resulting or actual moral use. Because the building did not engage the city's particular circumstances, as detailed earlier, but rather remained wantonly ignorant, rendering any genuine possibility of moral use absent. Instead, the project can today be understood as immoral from its conception because there were evidently no grounds on which moral relationship could have taken place. Even on the least demanding reading of knowledge of others that, for Cavell, is indispensable prerequisite for 
moral (inter)action, the City of Detroit appears to have acted in moral ignorance, while pursuing a course of moral(izing) action. ${ }^{16}$

\section{Conclusion}

Buildings can be, and often are, used in ways that have implicit or explicit moral significance. Whether an existing building has lived up to the promises of its private and political stakeholders, a new one can conceivably meet the stakeholders' promises, or a re-visioning of an old building can re-enliven hope in a failed promise, buildings contribute to a moral position of those that design, fund and otherwise partake in the process of determining the form, composition, program, and function of a building. By way of example, the moral relationship embodied by the Renaissance Center depicts vast disparity between actual and claimed morality. This form of analysis relies on the premises that buildings can embody the knowledge and agreement required for (moral) relationship and that buildings artifacts of moral relationship, and therefore buildings are morally appraisable. In other words, reading buildings for their moral implications, leads us to assume that we can appraise buildings for their moral appropriateness. In the case of the Renaissance Center, we saw not just that the building has moral implication but that building's immoral use maybe viewed as a cause of the moral relationship's breakdown, or perhaps more provocatively, a symptom of moral decay.

To the degree that the moral analysis of the Renaissance Center has merit, the analysis certainly ought to have implications for contemporary Detroit. If we look to contemporary German society, which has referenced and continues to reference the atrocities of World War II as a way of engaging what it collectively intends to avoid, we see a society that engages in difficult conversations about their past and which takes regular action - at all levels of social life from the individual to the nation's president - to not repeat the errors of the past. Detroiters it seems should similarly draw on their experiences, as citizens and as a collective municipal body, to intentionally work against the actions or lack of action, and to not recreate the same configurations of unemployment and exclusion that was and arguably remains so epidemic in the city. How Detroiters accomplish this wiser and morally upright approach is hard to say, but certainly worth concerted and collective effort to investigate. Mumford promises that this effort will breath new life, one that we all learn from and seek to cultivate ourselves.

\section{Notes}

1. The quotation is lightly paraphrased from Mumford, Lewis. The City in History. London: Harcourt, 1961: 243.

2. This essay assumes that cities are unique in their composition, resisting easy generalization, and that the term the city carries several meanings (sometimes, several at once), including but not limited to the following: the political constitution, including city officials, administrators and political figures, and the city as an institution; the people living in the city, or the residents and inhabitants of the city, their social, political, religious, and other belief systems; and the physicality and locality of city, which includes the climate and geography, the buildings and roads, as well as the trash and pollution. Context will disambiguate the term's intended meaning(s) in later sections.

3. The reference cited here are but three of numerous reports, editorials, and blog posts discussing the problem of Detroit. Typically, the laymen's view is framed in terms of pure economics or race.

4. Suburbanization is a low-density configuration that demands wider physical mobility and typically generates economic dispersion.

5. The Kerner Report was commissioned by the National Advisory Commission on Civil Disorders. The commission was appointed by President Lyndon Johnson with the intention of uncovering the causes of urban riots, of which there were many across the country at this time, and to recommend solutions. The report is named for the commissioner's chair, Governor Otto Kerner, Jr.

6. See "Mapping the 'Social Field of Whiteness': White Racism as Habitus in the City where History Lives" by Melissa Hargrove, "Places of Inequality, Places of Possibility: Mapping 'Opportunity in Geography' Across Urban School Communities" by T.L. Green, and "Race and the Distribution of Social Physical Environmental Risk" by Amy Schulz by way of evidence that the racial segregation can be geographically understood.

7. The lack of moral relationship does not eliminate moral obligation in Cavell. Additionally, Cavell has a unique position on relationship, one that is based in knowing, such that knowing someone but not having a relationship, specifically a moral relationship, does not absolve one of moral obligation to that person if, say, that person were in need of, say, protect from an attacker, or food while starving, or shelter from extreme weather, and so on.

8. Modern democracy does not refer to the neo-liberal democracies commonly thought of today. 
The neo-liberal democracy of contemporary society does not appear in the United States until the Ronald Reagan presidency, whilst many of the issues Detroit suffers from took root well before Reagan came into office.

9. See "Buildings made Moral" by Pauline Lefebvre in Architecture Philosophy, for an example of another framework for understanding building morality.

10. See discussion on what constitutes a city (footnote 2).

11. For Wittgenstein disagreements only take place against the background of shared assumptions. Shared assumption, as the framework dictates, is a pre-requisite of agreement.

12. See Cavell's discussion on the natural and conventional in Chapter 5 of The Claim of Reason and Ben Tilghman's essay “Architecture, Expression and the Understanding of a Culture" in Reflections on Aesthetic Judgement and Other Essays for in depth discussions on the traditional and conventional as distinct from notions of habit.

13. The Republican Party would go onto hold its 1980 national convention in the Renaissance Center. Detroit local and leftist activist Grace Lee Boggs likely contended with the massive investment in the Renaissance Center and its use for elite events in the midst of Detroit's woes. Evidence of this hypothesized position can be found in the following quotation: "We must give up many of the things which this country has enjoyed at the expense of damning over one-third of the world into a state of underdevelopment, ignorance, disease and early death" (Boggs, Boggs 1974: 140). One of the things we must give up is luxury conference centers, or in the very least prioritize the well-being of all over the creation of luxury spaces.

14 . The funds raised totaled $\$ 337$ million (approximately $\$ 1.3$ billion today adjusted for inflation) - a considerable sum of money in the midst of a local economic depression.

15. The reading of the Renaissance Center in this way - a commonly accepted mode of analysis in the architecture discipline - is deterministic in origin and could be related to Heidegger's notion of dwelling, in the sense that the way we live shapes our buildings and vice versa. The main difference between the Heideggerian model and the Cavellian one is the location of morality. For Heidegger it is moral to have an intimate symbiotic relationship with building, whereas for Cavell simply having the relationship itself is not enough. Only certain ways of engaging in the relationship are moral, whereas others can be immoral or lacking morality. For an in depth exploration into the relationship between
Heidegger and Cavell, see Cavell's own analysis in part one of The Claim of Reason.

16. In this sense it fails the third criteria, in which it fails not only the other but also itself in not recognizing or understanding their own position.

\section{References}

Allen, D. 2009. Talking to Strangers: Anxieties of Citizenship since Brown v. Board of Education. Chicago: University of Chicago Press.

Boggs, G. L.; Boggs, J. 1974. Revolution and Evolution in the twentieth century. New York: Monthly Review Press.

Cable, D. 2013. Racial Dot Map, University of Virginia's Weldon Cooper Center for Public Research Demographics Research Group [online], [cited 17 August 2015]. Available from Internet: http://demographics.coopercenter.org/racialdot-map/

Cavell, S. 1979. The Claim of Reason. Oxford: Oxford University Press.

Gordon, A. 2005. The creation of homeownership: how new deal changes in banking regulation simultaneously made homeownership accessible to whites and out of reach for blacks, Yale Law Journal 115(1): 186-226.

Goldberger, P. 1977. A Modern Center in Detroit Sets Itself Apart from the City, The New York Times. 15 March, 1977: 16.

Hackman, R. 2014. Police tell Detroiters to buy guns in the city riven by race issues and crime, The Guardian [online]. [cited 17 August, 2014]. Available from Internet: https:// www.theguardian.com/money/2014/aug/17/police-gunsdetroit-crime-race-cost-issues

Kanner, G. 2013. Detroit and the Decline of Urban America, Michigan State Law Review 5: 1547-1564.

Kerner, O.; John Lindsay, Fred Harris, Edward Brooke, James Corman, William McCulloch, I.W. Abel, Charles Thorton, Roy Wilkins, Katherine Graham Peden, Herbert Jenkins. 1968. National Advisory Commission on Civil Disorders Report. New York: Bantam Books.

Marger, M. 1979. Ethnic Succession in Detroit Politics, 19001950, Polity 11(3): 340-361. https://doi.org/10.2307/3234313

Maynard, M.; Blunkley, N. 2008. Motown is bleak as big three could become two, The New York Times. 30 October, 2008: B1.

McDougall, H. A. 1987. Affordable housing for the 1990s, University of Michigan Journal of Law Reform 785-786: 727-787.

Mumford, L. 1961. The City in History. London: Harcourt.

Romney, M. 2008. Let Detroit Go Bankrupt, The New York Times. 18 November, 2008: A35.

Seigel, R. 1997. Detroit public housing units to be torn down despite housing shortage, Michigan Citizen. 29 November, 1997: A5.

Stevens, W. 1977. Revitalizing Effect of Renaissance Center is Upgrading Detroiters' View of their City, The New York Times. 28 August, 1977: 26.

Stuart, R. 1978. Building Plans in Detroit raising hope for future; reasons for optimism, The New York Times. 8 November, 1978: A18.

Stuart, R. 1979a. Detroit Takes Convention News as a Sign Renewal is Succeeding; Next Target: Democrats, The New York Times. 24 January 1979: A10. 
Stuart, R. 1979b. “That Thing Up There” Worries Detroit; "Urban Renaissance", The New York Times. 14 November, 1979: 21.

Sugrue, T. 1996. The Origins of the Urban Crisis. Princeton: Princeton University Press.

United States Census Bureau [online], [cited 17 August. 2015]. Available from Internet: https://www.census.gov/ 2010census/data/other-census-data.php

Wacquant, L. 1997. Three pernicious premises in the study of the American ghetto, International Journal of Urban and Regional Research 21(2): 341-353.

https://doi.org/10.1111/1468-2427.00076
Wittgenstein, L. 1951. Philosophical Investigations. Oxford, Basil Blackwell.

Woodford, F. 1942. Detroit's housing shortage acute: family groups see homes in vain as they pour in, The New York Times. 9 August, 1942: E10.

\section{CAROLYN FAHEY}

Dr. Fahey is founding editor of Architecture Philosophy and has previously published with Architecture Research Quarterly. She currently works as an urban planner for the City of Boulder and is Fellow at the University of Colorado's Center for Sustainable Urbanism (CCSU). 